\title{
THE EFFECT OF HISTAMINE ON SKIN AND DEEP TEMPERA- TURES IN MAN WITH PARTICULAR REFERENCE TO LIVER TEMPERATURE
}

\author{
BY W. GRAF \\ (From the second Medical Service of St. Erik's Hospital, Stockholm, Sweden)
}

(Submitted August 21, 1956; accepted March 22, 1957)

Among the numerous investigations on the effects of histamine on regional temperatures and heat regulation the following reports deserve mention as they deal with problems related to the present investigation:

Dale and Laidlaw (1) reported that a large dose of histamine lowered the body temperature of dogs and guinea-pigs. Harmer and Harris (2) administered a moderate dose of histamine to humans, resulting in an increase of the skin temperature and a rise of rectal temperature. These authors suggested that the opposite effect on the rectal temperature would have seemed more likely. Thiessen and Snell (3), in a series of peptic ulcer cases, found that subsequent to a histamine dose gastric temperature fell whereas oral and rectal temperatures rose. Deutsch, Spitzy and Wohlrab (4) stated that after a dose of histamine the gastric temperature fell to the same extent in achlorhydric cases as in normals. The conclusion was drawn that gastric temperature and secretion are not related to each other. Henning, Demling and Kinzlmeier (5) considered measurement of the gastric temperature a possible method of studying, indirectly, blood flow to the stomach mucosa. They also investigated the reactions of the gastric temperature to certain stimuli $(6,7)$. The lowering of gastric temperature induced with histamine was interpreted as being due to hyperemia with slow blood flow. Spang, Obrecht and Ey (8) obtained the corresponding effect of histamine on gastric temperautre but did not consider it justifiable to look upon the gastric temperature as representative for blood flow fluctuations. They also stated that the temperature changes in the stomach do not differ from the pattern of other inner organs. Masuda, Ohara and Katsura $(9,10)$, in a series of experiments on the temperature of the gastrointestinal tract, concluded that gastric temperature and its changes after a histamine dose are related to the blood flow but not to the gastric secretory activity. Benjamin, Wagner, Zeit, Pisciotta, and Ausman (11), in a study of gastric temperature, claimed that in achlorhydria "intragastric temperature was a straight line tracing." These data are entirely contradictory to the findings of other authors (4). Rossi-Espagnet and Torlontano (12) postulated that the decrease in stomach temperature induced with histamine resulted from cooling of the blood circulating in the dilated skin vessels but offered no direct evidence in support of this opinion. Various authors working with animal experiments have previously expressed this view $(13,14)$.

\section{METHODS}

The procedure applied was described in a previous paper (15). Thermocouple units of copper/constantan or chrome-nickel/constantan were used as measuring units with a common reference junction, and the apparatus was built to compensate for variations in room temperature. ${ }^{1}$ The constantan wires measured $0.15 \mathrm{~mm}$. in diameter; the size of the copper wires was $0.08 \mathrm{~mm}$. The size of the junction was $0.5 \times 0.3 \mathrm{~mm}$. Junctions and wires were insulated in a nylon tube, the outer diameter of which was $1.55 \mathrm{~mm}$. It was repeatedly checked by means of ice and a heated medium, respectively, so that heat conduction along the thermocouple wires did not distort the results. The measuring units were introduced into the stomach (pyloric region), in the rectal ampulla (immediately above the sphincter), and in the liver. The thermocouple intended for the liver was sterilized for 18 to 24 hours in a 2 per cent solution of benzethonium chloride (NNR) and introduced through a Vim-Silverman-Boecker needle immediately following liver biopsy. The position of the thermocouple in the liver was in several instances controlled by X-ray in two planes. Skin temperature was measured by a thermocouple lightly applied to the center of manubrium. In some cases skin temperature was also measured at the anterior surface of the foreleg. In a few instances the temperature was measured in the right or left hepatic vein, the thermocouple being introduced through a cardiac catheter under fluoroscopic control.

The 40 male patients examined in the present investigation were all admitted to the hospital with alleged or

1 Equipment built by Ellab, Ltd., Copenhagen. 
previously confirmed liver disease. The livers were diagnosed on biopsy as being normal, fatty or cirrhotic but no characteristic differences in temperature pattern between normal and diseased livers have thus far been recognized.

The temperature-measuring equipment was repeatedly checked against a certified mercury thermometer in a water bath of constant temperature, adjusted to different levels between 36 and $38^{\circ} \mathrm{C}$. The accuracy of the measuring procedure was found to be $\pm 0.05^{\circ} \mathrm{C}$. As long as the thermocouples mutually yielded entirely uniform figures, small divergences $\left(0.05\right.$ to $0.1^{\circ} \mathrm{C}$.) from the mercury standard were allowed. The room temperature was constant within $0.5^{\circ} \mathrm{C}$. during most of the experiments, and within $1.0^{\circ} \mathrm{C}$. in a few. It differed slightly with the seasons of the year (between 18 and $24^{\circ} \mathrm{C}$.) ; in the investigations reported, room temperature variations and changes were not found to exert any influence on the organ temperature patterns examined.

Temperature readings commenced at 9:00 to 9:30 A.M. All subjects had fasted for nine hours and each received a sedative (see below) 30 minutes prior to the liver biopsy. At the hour mentioned, some of the patients offered a relative, or apparent, temperature equilibrium with only small deflections in the temperature curves of the different organs. Other subjects, however, showed at the same hour a tendency for slow fall of temperature in all organs. In these cases it was necessary to wait until the temperature seemed stable enough for experimental procedures. Thus some of the experiments were carried out before noon and others after. In the series of experiments with histamine, reproduced in Figure 1, the smaller and larger dose was given alternatively during morning and afternoon hours in order to reduce as far as possible the influence of spontaneous diurnal temperature shifts during the period in question (9:00 A. M. to 2:00 P.M.).

\section{Drugs used}

Histamine. A 0.1 per cent solution of 4 - ( $\beta$-aminoethyl)-imidazol dihydrochloride was used in doses of $1 / 2$ to $1 \mathrm{ml}$. given subcutaneously.

Amobarbital. A $0.1 \mathrm{Gm}$. dose was given orally in each case 30 minutes prior to the liver biopsy.

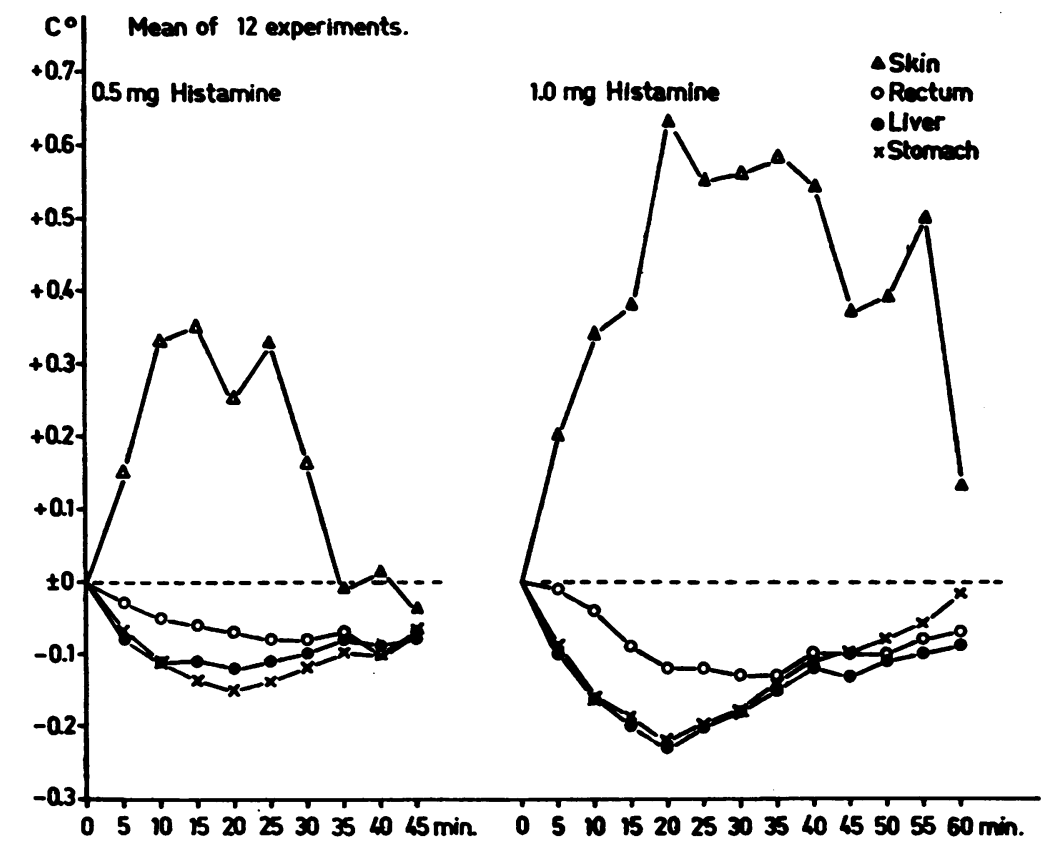

Fig. 1. Effect of Histamine on Skin and Deep Temperatures

Mean values from 12 cases (see also Table I). Ordinate: change in centigrades from temperature at histamine injection. Abscissa: time in minutes from injection. Absolute temperatures at 0 time:

\begin{tabular}{llllll} 
& \multicolumn{2}{c}{$\mathbf{0 . 5}$ mg. histamine } & & \multicolumn{2}{c}{ 1.0 mg. histamine } \\
\cline { 2 - 6 } Mean & S.E. & & Mean & S.E. \\
Rectum & $37.23^{*}$ & 0.067 & & $37.21 \dagger$ & 0.070 \\
Stomach & 37.11 & 0.044 & & 37.12 & 0.071 \\
Liver & $36.80^{*}$ & 0.076 & & $36.82 \dagger$ & 0.081
\end{tabular}

* Difference $0.43 \pm 0.10^{\circ} \mathrm{C}$., $\mathrm{P} \cong 0.001$.

$\dagger$ Difference $0.39 \pm 0.11^{\circ} \mathrm{C}$., $\mathrm{P}<0.01$. 
Promethazine. (N-( $\beta$-methyl- $\beta$-dimethylaminoethyl)phenothiazine chloride) was used as Lergigan $(8$, brand of Recip Ltd., Stockholm, in doses of $25 \mathrm{mg}$., given intramuscularly.

Dilatole. A brand of Troponwerke, Köln, (1-(p-oxyphenyl) -2 - (1'-methyl - $3^{\prime}$ - phenylpropylamino) - propanolhydrochloride), was given in doses of 5 to $10 \mathrm{mg}$. subcutaneously.

\section{RESULTS}

\section{Organ temperatures during the initial phase of measurement}

In those cases where the organ temperatures studied displayed a relatively stable level during the first 30 minutes after applying the thermocouples the experimental arrangements were started without further delay. In cases, however, which showed mobile temperature levels in the shape of a slow fall, the experiments had to be postponed, as mentioned above, until the temperatures leveled off, which occurred within 1 to 2 hours. This fall in temperature did not represent the normal trend of the diurnal rhythm during these hours. In the present material 15 cases were selected to illustrate the initial temperature fall described by Renbourn and Taylor (16). In these 15 cases the temperature at the start of the measurements was set as zero value and the subsequent changes from this value during 90 minutes are reproduced in Figure 2 (mean values, $n=15$ ). At 40 minutes the rectal temperature had a value of $-0.13 \pm 0.015^{\circ} \mathrm{C}$., whereas the corresponding figure for the stomach was -0.25 $\pm 0.029^{\circ} \mathrm{C}$. The difference between the two organs $\left(0.12 \pm 0.032^{\circ}\right.$ C. $)$ has a $\mathrm{P}$ value $<0.01$ and is thus statistically significant, implying that the lag of the rectal temperature is a real one.

After 90 minutes, or slightly more, a relative stabilization occurred. It is possible that the initial temperature drop in these cases was due to an increased "invisible perspiration" as a sign of stress, but the skin temperatures corresponding to the organ temperatures in Figure 2 did not show any characteristic tendency. In any case, the experimental measures were postponed until the temperature curves seemed to level off. In many cases, however, the curve appeared relatively flat from the beginning and the equilibration period was rather short. In no instance were the experiments started until 30 minutes after applying the measuring equipment in order to let the pa-

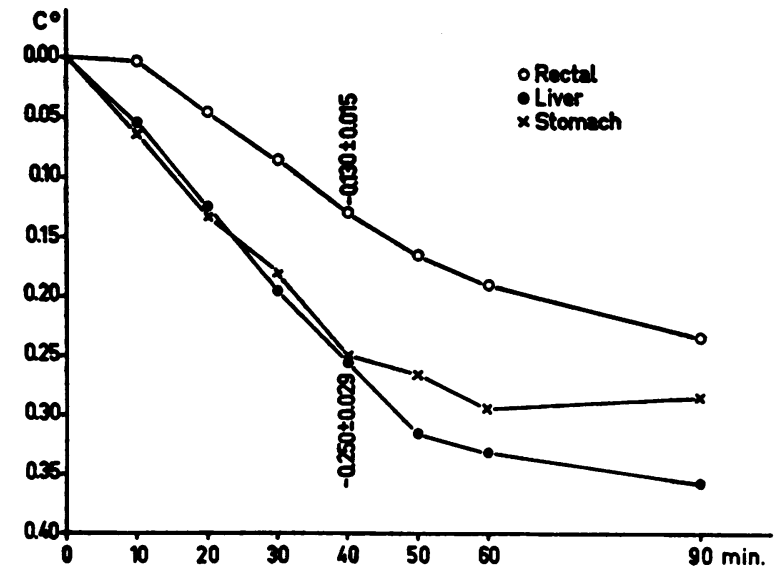

Fig. 2. Spontaneous Behavior of Organ TemperatURES When Starting the Experiment

Mean values from 15 selected cases. Ordinate: centigrade change from first measured value. Abscissa: time in minutes from beginning of experiment.

The difference between rectal and stomach temperatures as indicated at 40 minutes is $0.12^{\circ} \mathrm{C} . \pm 0.033$ (S.E.), $P$ value less than 0.01 .

tient relax after the liver puncture. The measurements were then continued for 3 to 7 hours, i.e., ending at from noon to 4 P.M.

\section{Mutual interrelationship between organ tempera- tures under study}

In a majority of cases the rectal temperature was highest, the gastric and liver temperatures running a few tenths of a degree centigrade lower. Occasionally, the liver was higher and also the stomach temperature was higher than the two others, but these cases were fairly exceptional. The relationships between the temperature curves of the three organs were relatively constant in one and the same subject but transient crossings sometimes occurred. Inverse relationships between the curves, as well as the mentioned crossings, seemed to lack implication to liver disease.

\section{The effect of histamine}

The effect of 0.5 and $1.0 \mathrm{mg}$. histamine dihydrochloride on the temperature curves of skin (manubrium), rectum, liver and stomach is shown in Figure 1. The centigrade level at the moment of the injection has been set as zero value and the subsequent deflections have been followed. The temperature changes from pre-injection level are also given in Table I. The smaller dose elicits 
TABLE I

Effect of $1 \mathrm{mg}$. histamine administered subcutaneously in terms of changes from temperature levels before the injection. Means and standard errors of 12 cases

\begin{tabular}{ccccc}
\hline \hline $\begin{array}{c}\text { Minutes } \\
\text { after } \\
\text { injection }\end{array}$ & Liver & Stomach & Rectal & Skin \\
\cline { 2 - 5 } & $-0.10 \pm 0.018$ & $-0.09 \pm 0.026$ & $-0.01 \pm 0.012$ & $+0.20 \pm 0.089$ \\
\hline 5 & $-0.16 \pm 0.016^{*}$ & $-0.16 \pm 0.030$ & $-0.04 \pm 0.015^{*}$ & $+0.34 \pm 0.117$ \\
10 & $-0.20 \pm 0.019$ & $-0.19 \pm 0.021 \dagger$ & $-0.09 \pm 0.024 \dagger$ & $+0.38 \pm 0.116$ \\
15 & $-0.23 \pm 0.020$ & $-0.22 \pm 0.023$ & $-0.12 \pm 0.026$ & $+0.63 \pm 0.156$ \\
20 & $-0.20 \pm 0.028$ & $-0.20 \pm 0.023$ & $-0.12 \pm 0.022$ & $+0.55 \pm 0.181$ \\
25 & $-0.18 \pm 0.028$ & $-0.18 \pm 0.027$ & $-0.13 \pm 0.023$ & $+0.56 \pm 0.194$ \\
30 & $-0.15 \pm 0.032$ & $-0.14 \pm 0.032$ & $-0.13 \pm 0.024$ & $+0.58 \pm 0.225$ \\
35 & $-0.12 \pm 0.032$ & $-0.11 \pm 0.035$ & $-0.10 \pm 0.023$ & $+0.54 \pm 0.244$ \\
40 & $-0.13 \pm 0.042$ & $-0.10 \pm 0.039$ & $-0.10 \pm 0.029$ & $+0.37 \pm 0.232$ \\
45 & $-0.11 \pm 0.032$ & $-0.08 \pm 0.051$ & $-0.10 \pm 0.026$ & $+0.39 \pm 0.206$ \\
50 & $-0.10 \pm 0.043$ & $-0.06 \pm 0.054$ & $-0.08 \pm 0.043$ & $+0.50 \pm 0.248$ \\
55 & $-0.09 \pm 0.034$ & $-0.02 \pm 0.047$ & $-0.07 \pm 0.037$ & $+0.13 \pm 0.124$ \\
60 & & & & \\
\hline
\end{tabular}

* Difference between liver and rectum at 10 minutes $=0.12 \pm 0.022^{\circ} \mathrm{C} .(\mathrm{P}<0.001)$.

$\dagger$ Difference between stomach and rectum at 15 minutes $=0.10 \pm 0.032^{\circ} \mathrm{C} .(\mathrm{P}=0.01)$.

an average skin temperature rise of $0.35^{\circ} \mathrm{C}$., with a concomitant fall of the "deep" temperatures. These display a very uniform pattern, the rectal temperature showing, however, slower fluctuations than the gastric and liver temperatures. No statistical difference was found to exist between the two latter temperature curves. After 45 minutes, all temperatures were back in the vicinity of the pre-injection level. Later on the curves were less representative, being influenced by the diurnal rhythm shift. The experiments were performed on fasting subjects, alternating during morning or afternoon hours. With the larger dose the rise of skin temperature and fall of rectal, hepatic and gastric temperatures were more pronounced, amounting to +0.6 and $-0.2^{\circ} \mathrm{C}$., respectively. In this series, the parallelism between liver and stomach temperatures is even more conspicuous and so is the somewhat tardy character of reaction of rectal temperature. At 20 minutes after

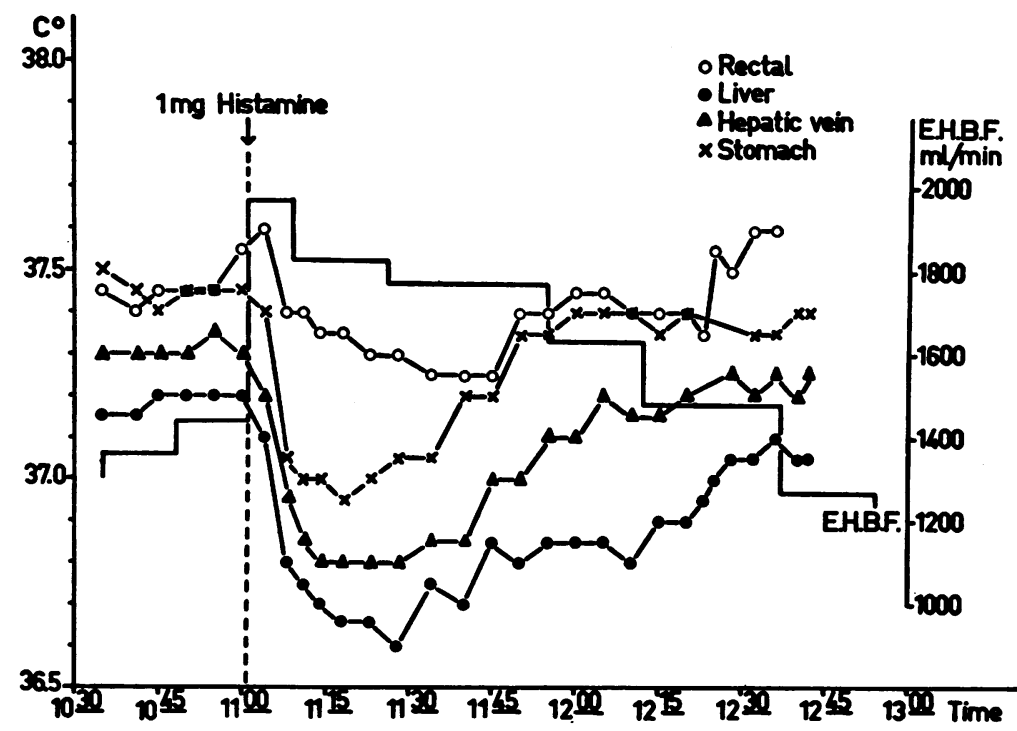

Fig. 3. EFfect of 1.0 Mg. Histamine

Ordinate: organ temperatures and liver blood flow, respectively. Abscissa : time.

The liver blood flow has been determined with bromosulphalein technique according to Bradley, Ingelfinger, Bradley and Curry (42). 


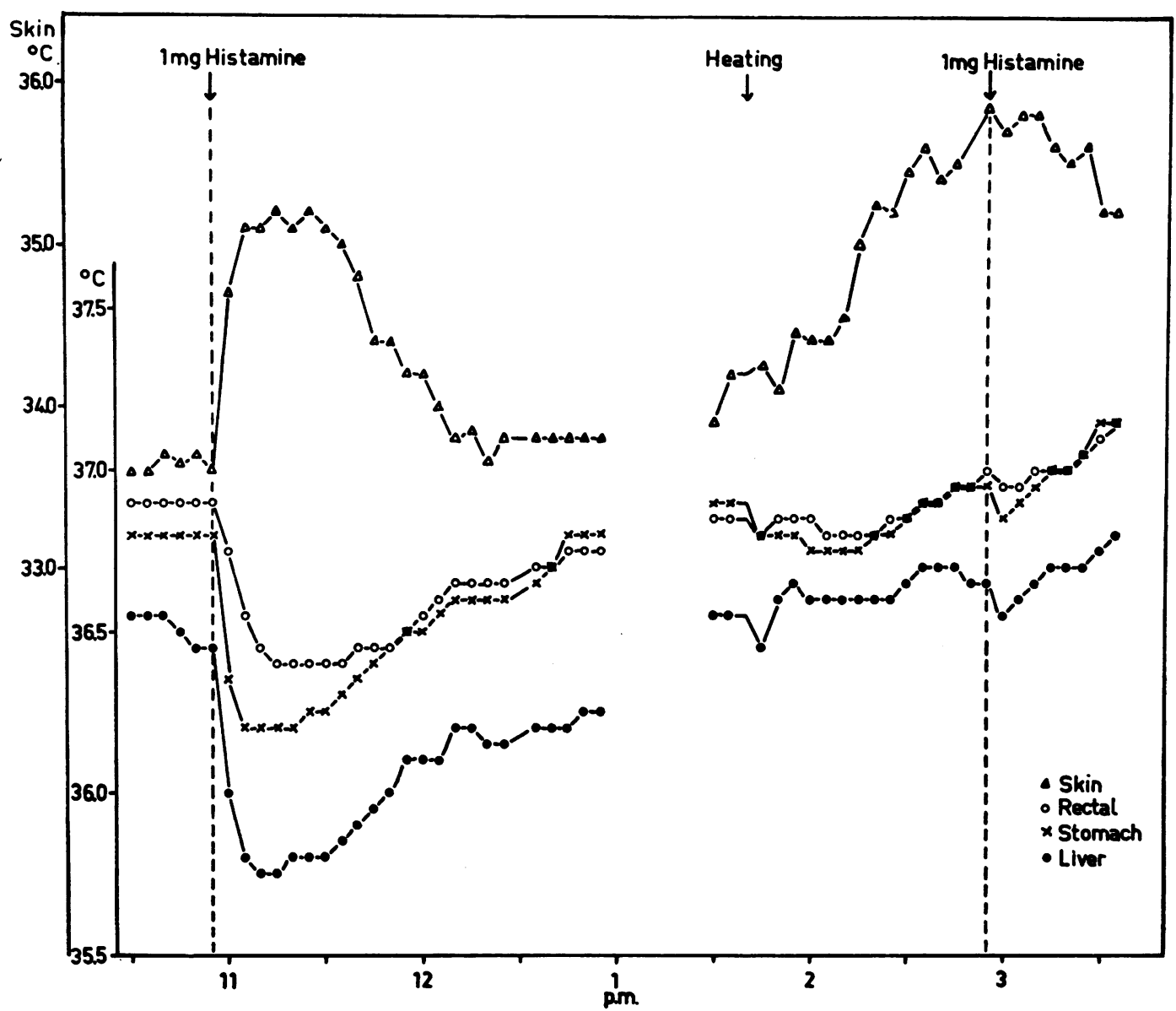

Fig. 4. Effect of Histamine Before and During Warming of Patient

Ordinate: extreme left scale refers to skin temperature and has been lifted in relation to inner scale, which refers to inner organs. Abscissa: time.

Histamine was administered before and after the patient was put under a heating cradle. The temperature-lowering effect was almost entirely abolished.

the larger dose the difference in temperature between rectum and liver is $0.11 \pm 0.03^{\circ} \mathrm{C}$., which means that the less pronounced and delayed response of rectal temperature to histamine is statistically significant $(p<0.01)$. In cases where prior to the histamine injection rectal temperature was lower than stomach and/or liver temperatures, the relations were often reversed when the effect of histamine appeared.

In Figure 3 an experiment is reproduced where the temperature in the right hepatic vein was also measured and is seen to behave in the same way as the gastric and the hepatic parenchyma temperatures. The difference between the liver parenchyma and the liver vein in this experiment is at times only $<0.1^{\circ} \mathrm{C}$., which closely approaches the margin of the measuring error.

Figure 4 demonstrates the effect of histamine before and during warming of the patient. The subject was put in a semicylindrical radiant heatcradle, with a total effect of 900 watts, which covered the torso. The extremities were covered with cloth to prevent loss of heat and thus only face and neck were bare. The lowering effect of $1 \mathrm{mg}$. histamine on rectal, stomach and liver temperatures was almost entirely eliminated.

\section{Effect of histamine in cases of achlorhydria}

In two cases of achlorhydria, repeated histamine doses regularly had the same effect on the tem- 
perature curves as in cases with a normal or increased hydrochloric acid secretion. On account of the limited number of observations the exact figures are not reported.

\section{Effect of anti-histaminic substance on histamine action}

In four cases 0.025 gram of promethazine (Lergigan $\left.{ }^{(}\right)$was given 30 minutes prior to a 1 mg. histamine dose. Promethazine did not seem to influence the temperatures measured in any way. A 0.1 to $0.4^{\circ} \mathrm{C}$. decrease of stomach and liver temperatures (quite congruent) occurred 5 to 20 minutes after the histamine injection, and in three of the four cases a corresponding skin temperature peak appeared (in the fourth case the histamine-induced vasodilation evidently did not affect the skin area of manubrium used for measuring).

It was concluded that the effect of histamine on the temperatures of body surface and inner organs is not notably influenced by promethazine.

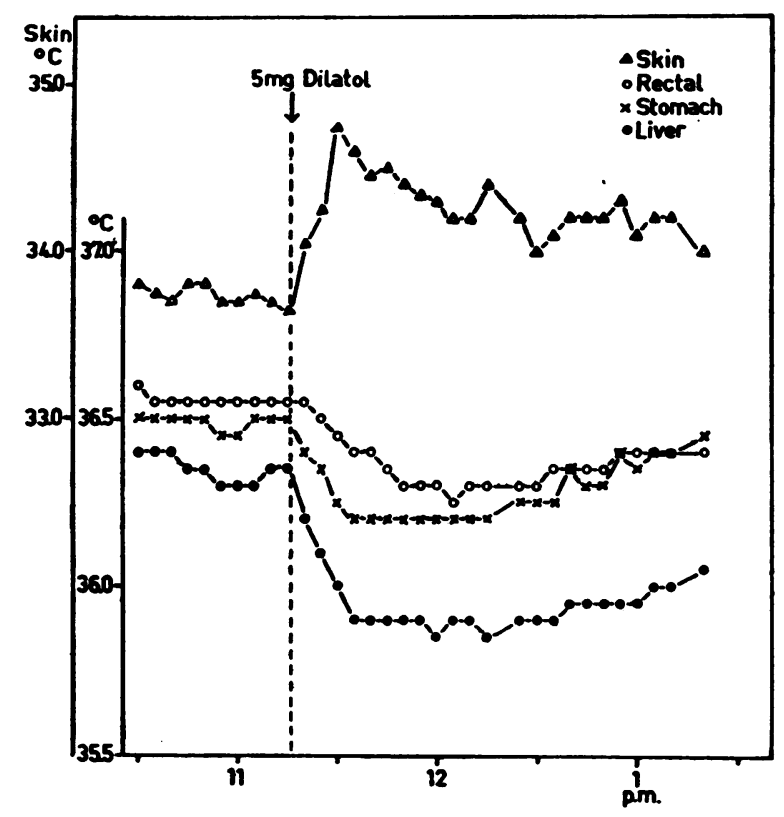

Fig. 5. Rise of Skin Temperature and Fall of DeEp TeMperatures After Administration of 5 Mg. Dinatol:8

Ordinate: as in Figure 4. Abscissa: as in Figure 4. See text.
Comparison of histamine effect to vasodilatation otherwise elicited

In Figure 5 the effect of $5 \mathrm{mg}$. Dilatol is reproduced (one case selected from a series of eight subjects). The same rise of skin temperature and the corresponding opposite behavior of deep temperatures are obtained as with histamine. Dilatol${ }^{\circ}$, however, in this case gave an effect of longer duration. In four out of eight cases, Dilatol ${ }^{\circ}$ failed to give a characteristic effect, the individual variations in vascular sensitivity to this drug being seemingly greater than to histamine.

\section{DISCUSSION}

The equipment used in the present investigation might seem to have a fairly great methodological error when compared to certain procedures described in the literature where equipment is repeatedly stated to have an accuracy of 0.005 to $0.01^{\circ} \mathrm{C}$. In the present investigation such extremely sensitive instruments are not necessary since spontaneous temperature fluctuations occur unceasingly, having at all the measurement spots a magnitude of 0.05 to $0.1^{\circ} \mathrm{C}$. per 5 minutes. These fluctuations are met with even during rest and completely basal conditions (16). According to Menzel (17) and Sollberger (18), several more or less regular endogenous temperature fluctuations occur, having a more frequent periodicity than the well-known diurnal rhythm, and having their different wave lengths superimposed on the latter. Hence, an absolute steady state does not seem to exist. A temperature change of less than $0.05^{\circ} \mathrm{C}$. per 5 minutes, therefore, is seldom significant, and an accuracy of less than $\pm 0.05^{\circ} \mathrm{C}$ does not constitute an absolute condition when investigating the slow changes which have been studied here.

As mentioned above, Renbourn and Taylor (16) have dealt with the equilibration period when starting temperature measurements, and state, without any attempt to explain the phenomenon, that in general a fall in rectal temperature occurred during this period. During 40 minutes it amounted to $-0.18^{\circ}$ C. (S.D. $\pm 0.3^{\circ}$ C.) in Renbourn's quoted series (32 subjects). This figure corresponds fairly well to observations in the present investigation (rectal temperature at 40 minutes $=-0.13^{\circ}$ C. $\left(\right.$ S.E. $\pm 0.015^{\circ}$ C. $)$. 
General pattern of the organ temperatures measured

Behavior of gastric temperature. The temperature curves obtained from the stomach decidedly support the opinion that the existence of normal secretion or achlorhydria does not exert any influence on the stomach temperature and its reactions to histamine. Unlike Benjamin, Wagner, Zeit, Pisciotta, and Ausman (11), the author has found, in conformity with Deutsch, Spitzy and Wohlrab (4), that in achlorhydria the fall in temperature elicited with histamine is the same as in cases with normal secretion. The diversity of results with regard to gastric temperature in achlorhydric subjects could not be easily explained, but on the whole an entirely constant temperature level in the stomach (see Reference 11, Figure 3, page 568) seems very unlikely when all other organs show considerable variations.

Behavior of rectal temperature. Figures 1 and 2 show that rectal temperature does not display the same degree of reaction as do gastric and liver temperatures. The rectal temperature pattern shows a slower reaction and the amplitude of its deflections is smaller. The conclusion is therefore justifiable that rectal temperature is not a sensitive index of the rapid temperature fluctuations occurring in the body. Long ago it was suggested that rectal temperature was representative of the critical body temperature but some authors, e.g., Eichna, Berger, Rader and Becker (19), have stressed its inferiority, and Gerbrandy, Snell and Cranston (20) point out that sublingual as well as esophageal temperatures are far better indices of critical tissue temperature.

Mead and Bonmarito (21) performed measurements of rectal temperature gradients at different heights and found that the gastric temperature rose and fell more quickly than rectal temperatures.

Liver temperature. It has been reported that the temperature of the human liver was lower most of the time than the rectal temperature, but that a temporary reversal of the curves could occur, based upon measurings on eight subjects (15). Although this observation seemed inconsistent with some reports based on animal experiments (22-25), it is in agreement with Eichna, Berger, Rader and Becker (19), Hor- vath, Rubin and Foltz (26), and Sollberger (27) who, in studying the diurnal rhythm of rectal and liver temperatures in chickens, found the mean difference between rectum and liver to be +0.15 $\pm 0.02^{\circ} \mathrm{C}$ : in 127 animals. In a recent study on the distribution and regulation of temperature in the rat, Grayson and Mendel (28) found "no significant difference in temperature between the liver and the mesentery near the portal vein, from which it may be concluded that the blood entering the liver from the intestine by way of the portal vein was probably not cooler than the liver itself." In some of the experiments reported in the same work, the mesentery temperature was even slightly higher than that of the liver.

The material examined by the author in the present investigation amounts to 40 human subjects. In some of these the liver has been warmer throughout the observation period, and in others there has been a more or less transient reversal. On the whole, however, the liver temperature of humans did not seem to reach the height generally assumed. This finding appears less inconsistent with the general conception of the role played by the liver in heat production if the high hepatic blood flow is borne in mind. The heat produced by the liver tissue is thus carried away by the blood stream so rapidly that the temperature of the organ will remain fairly low, at least when compared to the rectum, the mucosa of which has greater possibilities of preserving the heat locally produced by the tissues.

It is also possible that the liver, under certain circumstances, actually absorbs heat rather than produces it. This possibility has been put forward previously by Nedzel (29) but does not seem to have been taken into further consideration. According to Miller, Schastnaya and Jutkevich, as cited in an article by Federov and Shur (30) the blood of the portal vein is warmer than the blood of the hepatic vein by $1.5^{\circ} \mathrm{C}$. Fedorov and Shur (30) also state that the blood of the portal vein may be warmer than that of the hepatic vein, although this is exceptional.

It might be reasonable to seek an explanation of the findings here reported from another point of view, i.e., why the rectal temperature is particularly high. In the report of Eichna, Berger, Rader and Becker (19), only 5 out of 144 intravascular temperatures measured on 24 subjects 
were higher than the rectal temperature of the same subjects. Reference can also be made to Mather, Nahas and Hemingway (31) who mention that "it has been recognized for some time that the rectal temperature in the normal animal is somewhat above that found in the great vessels." Trying to find the key to the considerable rectal heat, Bazett, in a personal communication to $\mathrm{Ru}$ bin, Horvath and Mellette (32), suggested that the fecal bacterial activity would partly be responsible, but the latter authors found no evidence of this.

Furthermore, it is interesting to observe that according to Klaften (33) and Netter (34) intrauterine temperature seems to lie higher still; according to Bergman (35) it exceeds rectal temperature by 0.3 to $1.0^{\circ} \mathrm{C}$, whereby it seems possible that pelvic temperatures in general are high in relation to abdominal ones.

Differences in measuring technique may partly account for contradictory results referred to and certainly it is important that the rectal temperature should be measured at a constant height since it seems to be lower when measured higher up in the rectum $(16,21)$.

The effect of histamine. Some of the authors quoted above have even yielded results contradictory to those described in this work. Harmer and Harris (2), as well as Thiessen and Snell (3), did not obtain the regular and uniform lowering of deep temperatures but an increase of rectal temperature and a dissociation of deep temperatures. Concerning the first of these reports, the material examined was rather small, and in the second the rectal temperature was measured with a mercury thermometer, which could scarcely be considered satisfactory.

Several authors dealing with the subject have neglected the increased heat loss by cutaneous vasodilatation as an explanation of the lowered "deep" body temperature induced with histamine and have merely suggested changes in blood flow, e.g., in the stomach, as an interpretation of the hypothermic effect of histamine $(3,6,9,10)$.

Results from animal experiments can hardly be accepted as valid for humans. Nonetheless, some of the studies on the mechanism by which histamine exerts its influence on "body" temperature of animals are of interest. Gyermek (13) found that the rectal temperature of rats exposed to an environmental temperature of $20^{\circ} \mathrm{C}$. fell from
36.8 to $34.1^{\circ} \mathrm{C}$. after injection with histamine. When the room temperature was changed to $30^{\circ} \mathrm{C}$. the rectal temperature of the animals rose $1.1^{\circ} \mathrm{C}$. The corresponding relations between room temperature and the thermal effect of histamine were observed in rats by Deutsch, Spitzy and Wohlrab (4) and by Fabinyi-Szebehely and Szebehely (14) in rats and mice. These authors thus draw the conclusion that the temperaturelowering effect on the body of histamine at ordinary or low room temperatures is due to increased heat loss through the dilated skin vessels, whereas Packman, Rossi and Harrison (36) suggest that a decreased heat production may partly be responsible for the effect in question.

It is reasonable and logical to assume that in humans, too, the lowering of central body temperatures elicited with histamine is secondary to the vasodilatation in the skin and increased loss of heat from the body surface. The reactions of humans seem to be identical with that of the animals in the quoted experiments, viz., when the environmental temperature is increased and heat loss thus prevented, the fall in temperature is eliminated or decreased. In Figure 4 a minute temperature fall occurs, presumably due to the fact that the head and neck are not enclosed in the cradle or covered. As reported by Bohnenkamp and Ernst (37), the face and neck have high values for heat radiation (calculations based on Stefan-Bolzmann's law) and consequently a considerable loss of heat can occur here.

Further evidence that histamine acts by means of increased heat loss is the fact that its effect can be imitated with other drugs capable of giving a skin vasodilatation, not only Dilato ${ }^{\circledR}$ as in Figure 5 , but also adenosine triphosphoric acid (author's experiments, not reported here). Dilatol ${ }^{\circledR}$ has been studied by Külz and Schneider (38), who found that in rabbits, cats and dogs small doses elicited a strong vasodilatation in skin and muscles. Hensel, Ruef and Golenhofen (39), studying the effect of Dilatol ${ }^{\circledR}$ on blood flow in the muscle and skin of eight human subjects, noticed a marked increase in blood flow in the muscles but practically none in the skin. Measurements in Hensel's investigations were, however, performed on the soles of the feet and presumably the blood vessels of the upper half of the body are more apt to react to this agent. Consequently, the tempera- 
ture-lowering effect of Dilatol demonstrated in Figure 5 may be due to cutaneous vasodilatation as well.

If the temperature-lowering effect of histamine were due to decreased heat production, it would be reasonable to suppose that a decrease of the basal metabolic rate occurred simultaneously. This, however, is not the case, either in animals (13), or in humans, where, e.g., von Euler and Liljestrand (40) obtained a 7 per cent increase of $\mathrm{BMR}$ at ordinary room temperature.

In the experiments reported in the present investigation, the liver and hepatic vein temperatures rose and fell simultaneously with the gastric temperature and no evidence was found that the temperature fall in the liver was less or slower when compared with that of the stomach. Kosaka (41), measuring temperatures in the portal and hepatic veins of dogs, found that when the animals were submitted to cooling the fall in temperature in the hepatic vein was much less than in the rectum, allowing the conclusion that heat production in the liver rapidly increased. The results reported above do not support the hypothesis of such a mechanism, as both liver parenchyma and liver vein temperatures reacted in the same way and to the same extent as did the other organ temperatures.

\section{SUM MARY}

1. Rectal, gastric, liver and skin temperatures in man have been measured with thermocouples.

2. The lowering effect of histamine was the same on liver and hepatic vein and gastric temperatures, but less marked on the rectal temperature. It corresponded in time to a rise in skin temperature and both effects were proportional to the histamine doses used.

3. The effect of histamine on gastric temperature was the same in achlorhydric patients as in individuals with normal hydrochloric acid secretion.

4. The effect of histamine could be imitated with other agents eliciting cutaneous vasodilatation. Only when a skin temperature rise occurred did the inner organs display a fall in temperature.

5. If cutaneous vasodilatation is induced by heating a subsequent histamine dose has but little effect on the temperatures.
6. It is concluded that the temperature-lowering effect of histamine is merely due to a transient increase of heat radiation from the skin. This interpretation corresponds to results from animal experiments reported by various authors.

\section{ACKNOWLEDGMENT}

The author is indebted to Recip Ltd., Stockholm, for valuable financial support of this investigation and to Miss A.-M. Allgoth for skillful technical assistance.

\section{REFERENCES}

1. Dale, H. H., and Laidlaw, P. P., Further observations on the action of $\beta$-iminazolylethylamine. J. Physiol., 1911, 43, 182.

2. Harmer, I. M., and Harris, K. E., Observations on the vascular reactions in man in response to histamine. Heart, 1926, 13, 381.

3. Thiessen, N. W., and Snell, A. M., The variations of intragastric temperature in response to vasodilating agents. Am. J. Physiol., 1933, 105, 665.

4. Deutsch, E., Spitzy, K. H., and Wohlrab, K., Ueber die Beeinflussung der Magentemperatur durch verschiedene Pharmaka. Arch. internat. pharmacodyn. et de thérap., 1951, 85, 369.

5. Henning, N., Demling, L., and Kinzlmeier, H., Utber ein Gerät zur fortlaufenden, gleichzeitigen Bestimmung wichtiger Magenfunktionen. Klin. Wchnschr., 1951, 29, 605.

6. Henning, N., Kinzlmeier, H., and Demling, L., Fortlaufende Registrierung verschiedener Magenfunktionen beim Menschen unter dem Einfluss von sekretions- und motilitätsfördernden Substanzen. Ztschr. f. d. ges. exper. Med., 1952, 118, 177.

7. Demling, L., Kinzlmeier, H., and Henning, N., Experimentelle Untersuchungen über die Wirkung inhibitorischer Pharmaka am menschlichen Magen. Gastroenterologia, 1952, 78, 269.

8. Spang, K., Obrecht, V., and Ey, W., Uber den Wert einer Messung der Temperatur des Magens für die Beurteilung seiner Durchblutung. Klin. Wchnschr., 1952, 30, 210.

9. Masuda, H., Ohara, M., and Katsura, S., Studies on the temperature of the gastrointestinal tract. Fifth report. Tohoku J. Exper. Med., 1953, 57, 129.

10. Masuda, H., Ohara, M., and Katsura, S., Studies on the temperature of the gastrointestinal tract. Sixth report. Tohoku J. Exper. Med., 1953, 57, 137.

11. Benjamin, H. B., Wagner, M., Zeit, W., Pisciotta, A., and Ausman, R. K., Intragastric temperatures in the achlorhydric patient. Surg., Gynec. \& Obst., 1955, 100, 566.

12. Rossi-Espagnet, A., and Torlontano, G., Relazione tra temperatura gastrica, secrezione gastrica e comportamento termico cutaneo e rettale. Boll. Soc. ital. biol. sper., 1955, 31, 1455. 
13. Gyermek, L., Die Wirkung des Histamins auf den Gasstoffwechsel und die Körpertemperatur. Arch. f. exper. Path. u. Pharmakol, 1950, 209, 456.

14. Fabinyi-Szebehely, M., and Szebehely, J., The influence of antihistamines on the effect of histamine upon body temperature and oxygen consumption in mice and rats. Acta physiol., 1952, 27, 1.

15. Graf, W., Porjé, I. G., and Allgoth, A.-M., Observations on the temperature of human liver parenchyma. Gastroenterologia, 1955, 83, 233.

16. Renbourn, E. T., and Taylor, P. F., Body temperature studies: Part II. Rectal and oral as indices of internal temperatures. Presented to the Fifth Commonwealth Defence Conference on Clothing and General Stores. Canada, 1956, p. 28.

17. Menzel, W., Klinische Ziele der Rhythmusforschung. Acta med. Scand. Suppl., 1955, 307, 107.

18. Sollberger, A., Diurnal changes in biological variability. Acta anat., 1955, 23, 259.

19. Eichna, L. W., Berger, A. R., Rader, B., and Becker, W. H., Comparison of intracardiac and intravascular temperatures with rectal temperatures in man. J. Clin. Invest., 1951, 30, 353.

20. Gerbrandy, J., Snell, E. S., and Cranston, W. J., Oral, rectal, and oesophageal temperatures in relation to central temperature control in man. Clin. Sc., $1954,13,615$.

21. Mead, J., and Bonmarito, C. L., Reliability of rectal temperatures as an index of internal body temperature. J. Applied Physiol., 1949, 2, 97.

22. Bernard, C., Recherches expérimentales sur la température animale. Compt. rend. Acad. d. sc., 1856, 43, 329.

23. Marshak, M. E., Temperature changes in the inner organs caused by warming and cooling the animal. Arch. sc. biol., 1939, 55, 21.

24. Nedzel, A. J., Temperature changes in the liver in relation to heat and cold on skin. Proc. Soc. Exper. Biol. \& Med., 1933, 30, 689.

25. Dietrick, R. B., and Fritts, J. M., Comparative measurements of temperature in liver, lung, and rectum of the rabbit. Proc. Soc. Exper. Biol. \& Med., 1952, 80, 293.

26. Horvath, S. M., Rubin, A., and Foltz, E. L., Thermal gradients in the vascular system. Am. J. Physiol., 1950, 161, 316.

27. Sollberger, A., To be published.
28. Grayson, J., and Mendel, D., The distribution and regulation of temperature in the rat. J. Physiol., 1956, 133, 334.

29. Nedzel, A. J., A study of muscle temperature during bacterial chill. Proc. Soc. Exper. Biol. \& Med., 1934, 32, 279.

30. Fedorov, N. A., and Shur, E. I., The rôle of the viscera in regulating the temperature of the body of an animal under physiological and pathological conditions. Am. J. Physiol., 1942, 137, 30.

31. Mather, G. W., Nahas, G. G., and Hemingway, A., Temperature changes of pulmonary blood during exposure to cold. Am. J. Physiol., 1953, 173, 390.

32. Rubin, A., Horvath, S. M., and Mellette, H. C., Effect of fecal bacterial activity on rectal temperature of man. Proc. Soc. Exper. Biol. \& Med., 1951, 76, 410.

33. Klaften, E. M., Utero-thermometry. J. Clin. Endocrinol. \& Metab. 1944, 4, 159.

34. Netter, A., La température cervico-utérine. Ann. d'endocrinol., 1947, 8, 194.

35. Bergman, P., Studies on ovulation time. Acta obst. et gynec. Scandinav., 1950, 30, 292.

36. Packman, E. W., Rossi, G. V., and Harrison, J. W. E., The effect of histamine and antihistamines on body temperature. J. Pharm. and Pharmacol., 1953, 5, 301.

37. Bohnenkamp, H., and Ernst, H. W., Úber die Strahlungsverluste des Menschen. Pflüger's Arch. f. d. ges. Physiol., 1931, 228, 63.

38. Külz, F., and Schneider, M., Über neue gefässerweiternde Sympatlicomimetica. Klin. Wchnschr., 1950, 28, 535.

39. Hensel, H., Ruef, J., and Golenhofen, K., Die Muskelund Hautdurchblutung des Menschen bei Einwirkung vasoaktiver Substanzen. Ztschr. Kreislaufforsch., 1954, 43, 756.

40. von Euler, U., and Liljestrand, G., Die Wirkung von Adrenalin, Sympathol, Tyramin, Ephetonin und Histamin auf Gaswechsel und Kreislauf beim Menschen. Skandinav. Arch. f. Physiol., 1929, 55, 1.

41. Kosaka, T., On heat production in the liver. J. Orient. Med., 1930, 12, 19.

42. Bradley, S. E., Ingelfinger, F. J., Bradley, G. P., and Curry, J. J., The estimation of hepatic blood flow in man. J. Clin. Invest., 1945, 24, 890. 